\title{
Age Dependency of Infradian Rhythms in Enzymuria of Female Volunteers
}

\author{
Axel Gerasch ${ }^{1}$, Ulf Burchardt ${ }^{2}$, Michael Klagge ${ }^{2}$ and Detlef Balschun ${ }^{3}$ \\ 1 Evangelisches Krankenhaus Lutherstift Frankfurt (Oder)/Seelow, Germany \\ 2 Klinikum Frankfurt (Oder), Frankfurt (Oder), Germany \\ ${ }^{3}$ Institut für Neurobiologie, Magdeburg, Germany
}

Summary: The enzyme excretion of dipeptidylpeptidase IV (EC 3.4.14.5), $\gamma$-glutamyltransferase (EC 2.3.2.2), and alanine aminopeptidase (EC 3.4.11) was pursued in three different age groups of female volunteers over a period of 70 days. The first group $(1-3$ years: $n=6)$ consisted of girls living in a children's home, the second $(26-50$ years, $n=7)$ of medical staff and the third (65-87 years, $n=7)$ of the inhabitants of an old-age home. Subsequent to basic statistics the excretion patterns were analyzed by spectral analysis with the maximum entropy method.

The mean values of all enzymes displayed a distinct age-dependency. The highest levels of enzyme excretion were found in the early childhood. In all groups infradian changes of enzyme excretion were detected. In excretion of $\gamma$ glutamyltransferase, longer periods between 12 and 24 days predominated during the early childhood, whereas in the middle, and in particular in the higher age, shorter dominant periods occurred more frequently. The excretion of alanine aminopeptidase displayed a similar tendency. Circaseptan periods ( $7 \pm 1$ days) were rarely observed among the dominant periods of the maximum entropy method spectra. A correlation analysis of the individual excretion patterns revealed that the excretion of all three brush-border enzymes is most tightly correlated in the early childhood (coefficients of correlation up to 0.9 ). In contrast, the correlation between enzyme and creatinine excretion was low in all age groups.

\section{Introduction}

The urine of healthy subjects contains small amounts of enzymes and other proteins which originate from the blood, the kidneys and the urinary tract. Information about the clinical value of the excretion of these proteins has been accumulated over the past decades. In particular, the altered appearance of lysosomal and tubular brush border enzymes in urine is indicative of various disorders of the urogenital tract $(1-5)$. However, the use of enzymuria in clinical routine $(6-11)$ has to contend with several difficulties such as a high inter-individual variation in the response of enzyme excretion to renal disorders $(12-14)$. It is well known that diuresis and the composition of urine is liable to ultradian, circadian and infradian rhythms. However, only a few studies have documented rhythmic changes in enzymuria so far $(7,15-18)$. In previous investigations on healthy volunteers we found infradian rhythms in the excretion of dipeptidylpeptidase IV, $\gamma$-glutamyltransferase, and alanine aminopeptidase $^{1}$ ) with an average period length of 1014 days (12). Patients who were therapeutically treated

\footnotetext{
1) Enzymes:

dipeptidylpeptidase IV, EC 3.4.14.5,

$\gamma$-glutamyltransferase, EC 2.3.2.2

alanine aminotransferase, EC 3.4.1.1
}

with the aminoglycoside gentamicin for 10 days displayed an enhanced occurrence of circaseptan periodicities $(7 \pm 1$ days $)$ in the excretion of alanine aminopeptidase, supporting the hypothesis that circasep$\tan$ periods are more abundant during reactive and adaptive phases of the organism $(12,19,20)$.

The goal of the present study was to investigate whether infradian rhythms in the excretion of tubular brush border enzymes are subjected to age-dependent changes.

\section{Materials and Methods}

The study was performed on female volunteers of three different age groups. The first group $(1-3$ years; $n=6)$ consisted of girls living in a children's home, the second $(26-50$ years, $n=7)$ of medical staff and the third $(65-87$ years, $n=7)$ of the inhabitants of an old-age home. For determination of enzyme activity, 10-20 $\mathrm{ml}$ of the morning urine was collected and processed within three hours as described previously $(12,13)$. In brief, the specimens were centrifuged at $1500 \mathrm{~g}$ for $10 \mathrm{~min}$ and cleared from endogenous effectors by gel filtration (21). Subsequently, the samples were stored at $-20^{\circ} \mathrm{C}$ until determination of enzyme activity.

The activities of alanine aminopeptidase, $\gamma$-glutamyltransferase, and dipeptidylpeptidase IV were determined by the use of chromogenic substrates and related to the creatinine content of the respective sample $(8,12,22,23)$.

Group differences were assessed by non-parametric Kruskal-Wallis one-way ANOVA and the Mann-Whitney U-test. Relevant period- 
icities were detected in a two-step-procedure in a similar manner as previously described (12).

1. In order to remove long-term, non-linear trends in the time series, the smoothing-mean over 10 consecutive values was subtracted from the original data. The particular smoothing interval was found to be optimal, i.e. it improved the resolution of the subsequent methods in the interesting frequency range but left the spectral composition nearly untouched.

2. The spectral composition of the data was assessed by the maximum entropy method. As proven by former additional non-linear fits of cosine functions, the maximum entropy method provides reliable data even if short time series are analyzed. Therefore, the spectral calculations were confirmed to maximum entropy method analysis. The spectral components (periods) which displayed the highest spectral density will be designated as "dominant periods" in the following. As another measure, the five periods with the highest power were averaged and designated as "mean period". Although the physiological significance of the mean period is uncertain, we believe that this measure provides valuable additional information about the time series, i. e. the mean period gives an indication of the preferred infradian period range.

Possible correlation between the analytes were detected by calculating Spearman's rank correlation coefficient and the corresponding coefficient of determination (\%) with the Statistics Package SPSS [SPSS GmbH München, Germany].

\section{Results}

Beyond their inherent rhythmicity, the urine excretion of all three investigated enzymes displayed a distinct agedependency that was statistically highly significant (except the difference between the alanine aminopeptidase values of the adult and senescent group). The highest levels of enzyme excretion were found in the early childhood as illustrated in figure 1 . Whereas dipeptidylpeptidase IV and alanine aminopeptidase exhibited a similar U-shaped age-course with a trough in the middle age (correlation coefficient between the individual mean values of both enzymes of $0.88 ; p<0.001$ ), the excre-

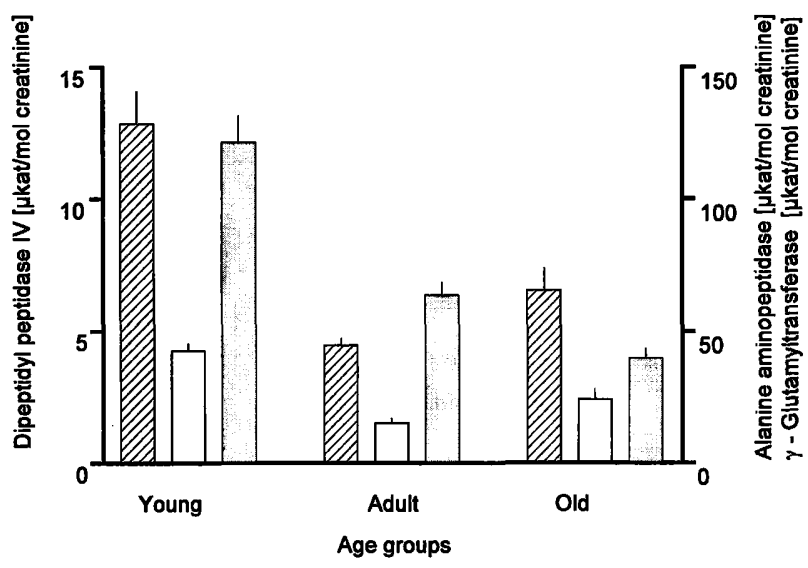

Fig. 1 Mean values of the enzyme excretion of three different age groups as determined in the morning urine during a 70 days recording period. The values were calculated from the individual means (over the 70 day recording period), which were subsequently assigned to the three age groups and averaged. Hatched bar: dipeptidyl peptidase IV; white bar: alanine aminopeptidase; black bar: $\gamma$-glutamyltransferase. The means \pm SEM are given. Notice the different scaling of the two ordinates. tion of $\gamma$-glutamyltransferase decreased linearly with age.

The enzyme excretion of all age-groups underwent infradian changes with a period range between 2 and 35 days. Only the alanine aminopeptidase- and $\gamma$-glutamyltransferase-excretion of a 50-year-old woman (volunteer 11) displayed dominant periods of 48 and 52 days, respectively. All time series showed clear-cut interindividual differences with respect to shape, spectral composition and amplitude. As exemplified in figure 2, the subtraction of the smoothing-mean over 10 values did not affect the time-course of the excretion pattern but removed long-term trends which would interfere with the subsequent maximum entropy method analysis. The maximum entropy method analysis revealed a significant age-dependency of the infradian rhythms in $\gamma$ glutamyltransferase excretion. As depicted in figure 3, during the early childhood longer periods between 12 and 24 days predominated. In the middle and in particular in the higher age shorter dominant periods occurred

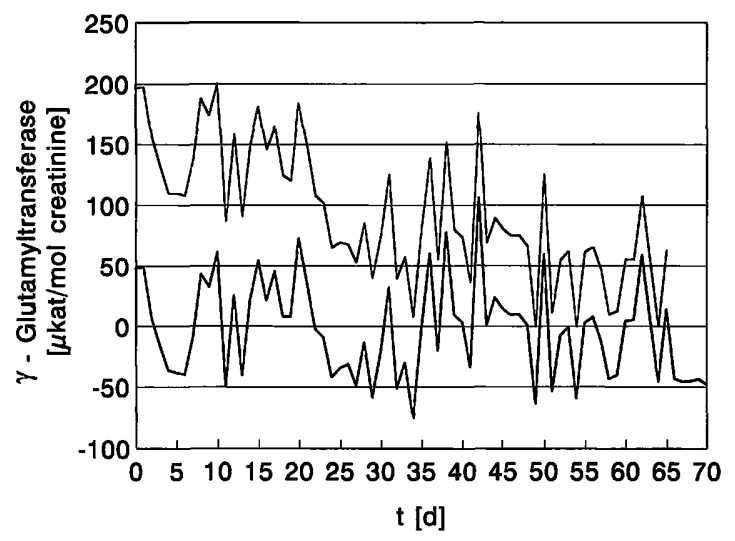

Fig. 2 Excretion of $\gamma$-glutamyltransferase of a two-year old girl (No. 4). Above: original time series, below: after removal of the smoothing mean over 10 values.

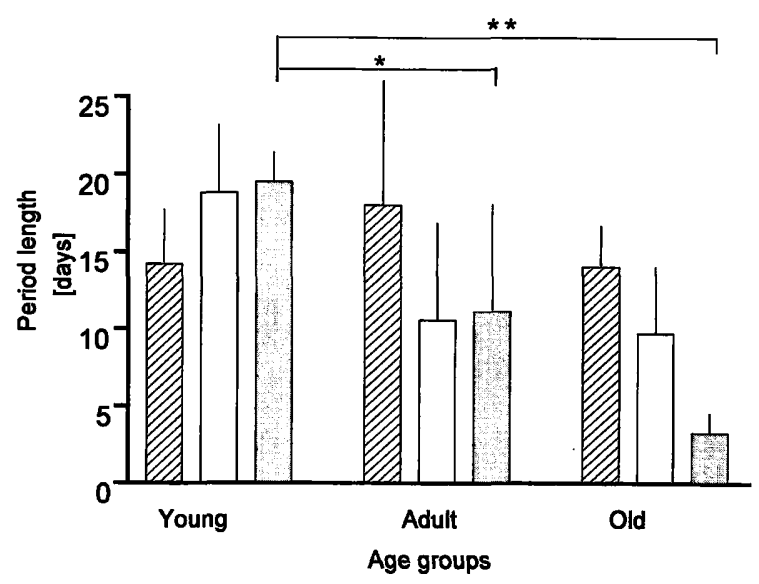

Fig. 3 Dominant periods in the excretion patterns of dipeptidylpeptidase IV, alanine aminopeptidase and $\gamma$-glutamyltransferase as calculated with the Maximum Entropy Method (MEM). Hatched bar: dipeptidyl peptidase IV; white bar: alanine aminopeptidase; black bar: $\gamma$-glutamyltransferase. The means \pm SEM are given. $* \mathrm{p}<0.05, * * \mathrm{p}<0.01$ 


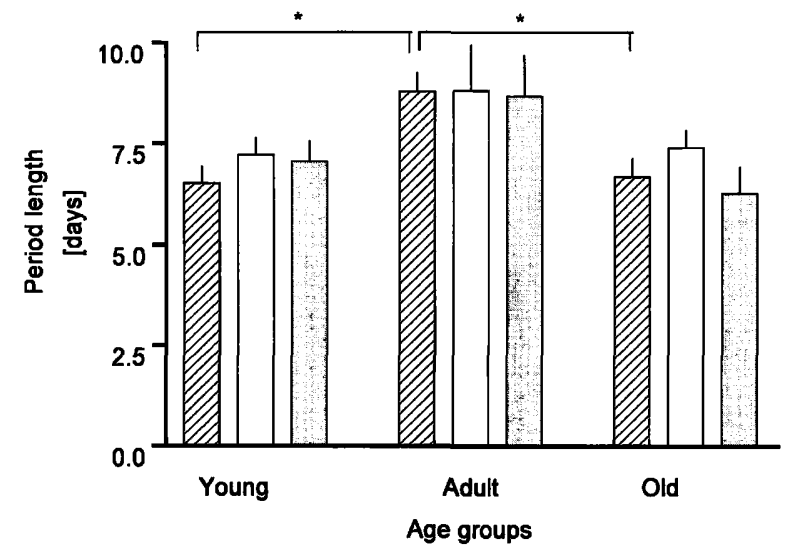

Fig. 4 Mean periods in the excretion patterns of dipeptidylpeptidase IV, alanine aminopeptidase and $\gamma$-glutamyltransferase. Hatched bar: dipeptidyl peptidase IV; white bar: alanine aminopeptidase; black bar: $\gamma$-glutamyltransferase. The means \pm SEM are given. ${ }^{*} \mathrm{p}<0.05$
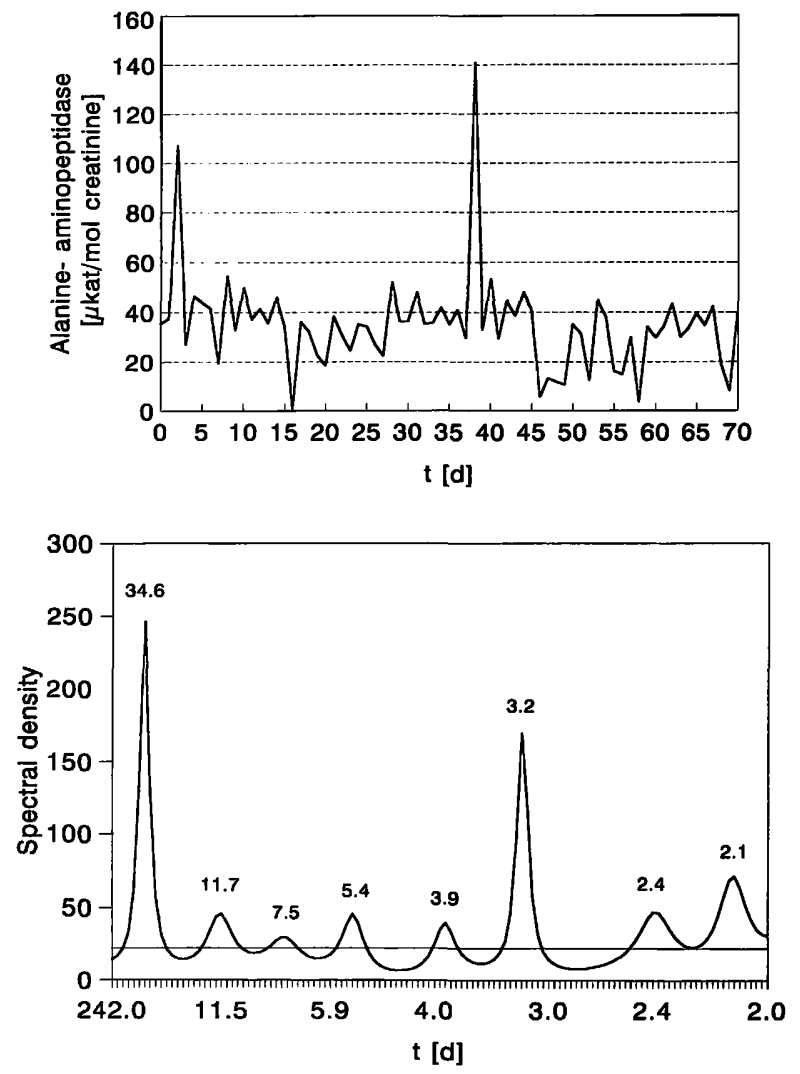

Fig. 5 Alanine aminopeptidase excretion of a two-year old girl (No. 2). Above: original time series, below: maximum entropy method spectrum. The horizontal line indicates the spectral density of "white noise".

more frequently. The alanine aminopeptidase excretion displayed a similar tendency which was however not statistically significant. The dipeptidylpeptidase IV patterns showed a high variance of dominant periods. In the senescent group the dominant periods of $\gamma$-glutamyltransferase were significantly shorter than those of dipeptidylpeptidase IV and alanine aminopeptidase ( $p<0.05$ for each comparison, U-test). In the other age groups no significant differences could be detected. Cir-
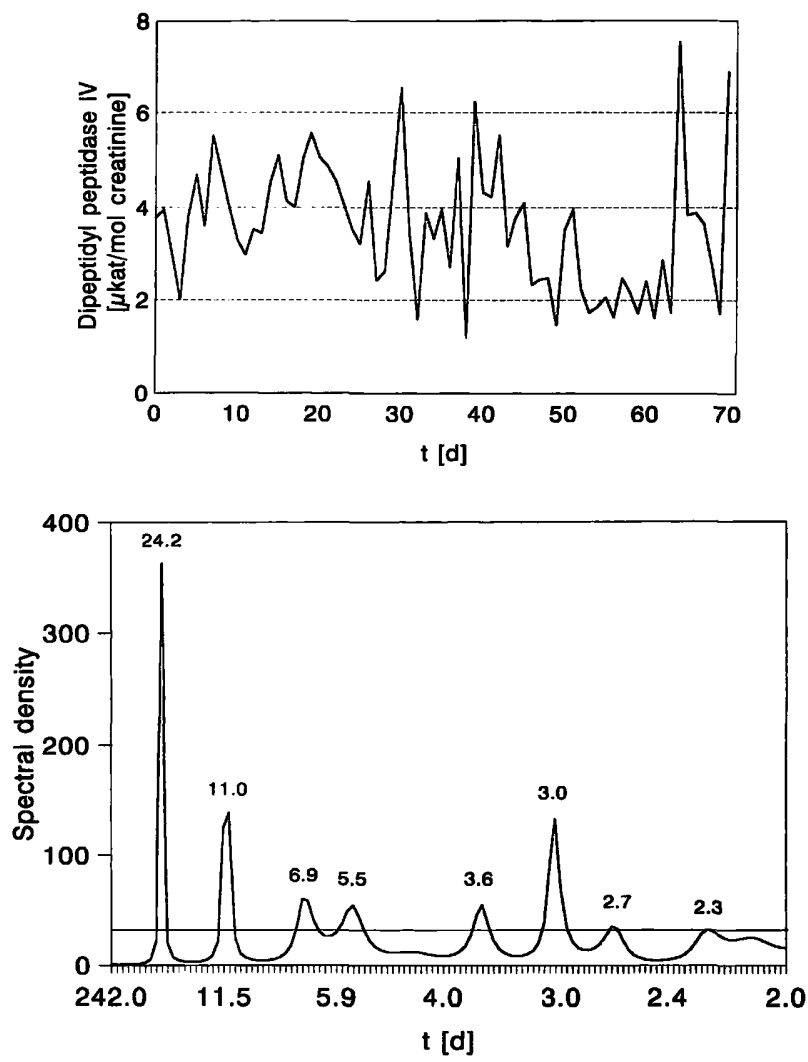

Fig. 6 Excretion of dipeptidylpeptidase IV of a 26-year old woman (No. 7). Above: original time series, below: maximum entropy method spectrum.
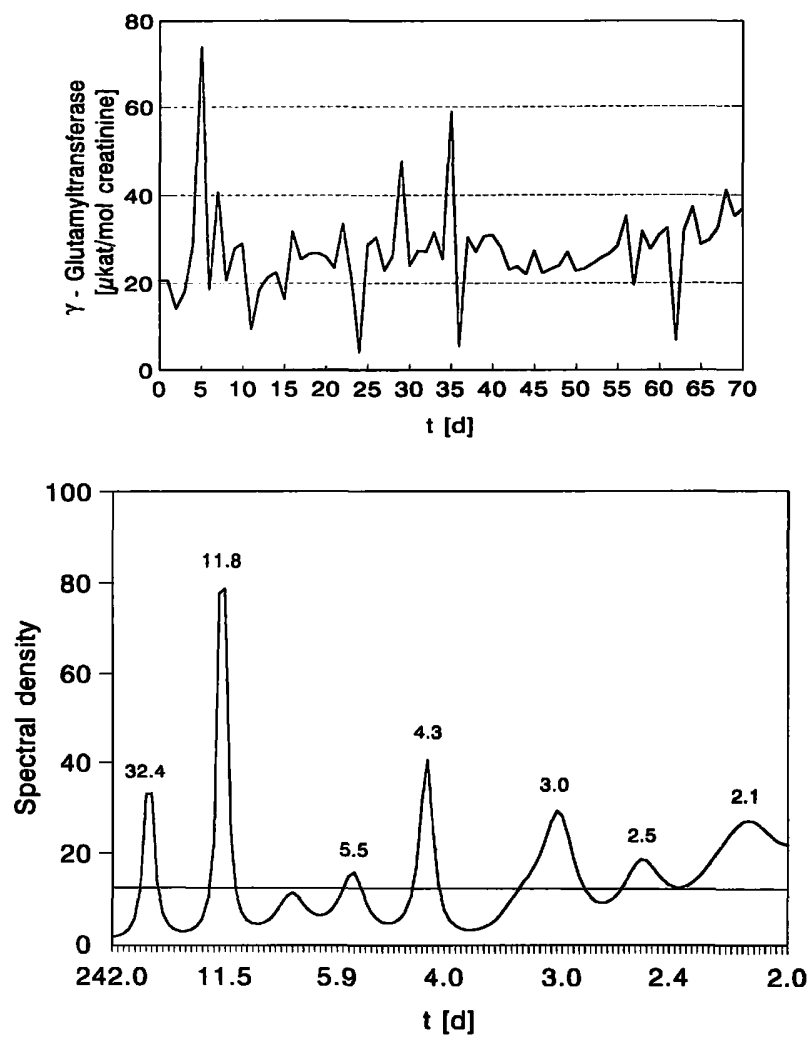

Fig. 7 Excretion of $\gamma$-glutamyltransferase of 65 -year old woman (No. 18). Above: original time series, below: maximum entropy method spectrum. 
Tab. 1 Correlation analysis between the catalytic activities of dipeptidylpeptidase IV, alanine aminopeptidase and $\gamma$-glutamyltransferase and the corresponding creatinine concentration in urine. Averages of the individual coefficients of determination are compiled. Means $\pm \mathrm{SEM}$ are given.

\begin{tabular}{|c|c|c|c|c|c|c|c|}
\hline \multirow[t]{2}{*}{$\begin{array}{l}\text { Age } \\
\text { group }\end{array}$} & \multirow[t]{2}{*}{ Analyte } & \multicolumn{2}{|c|}{$\begin{array}{l}\text { Dipeptidyl } \\
\text { peptidase IV }\end{array}$} & \multicolumn{2}{|c|}{$\begin{array}{l}\text { Alanine amino- } \\
\text { peptidase }\end{array}$} & \multicolumn{2}{|c|}{$\begin{array}{l}\gamma \text {-Glutamyl- } \\
\text { transferase }\end{array}$} \\
\hline & & mean & SEM & mean & SEM & mean & SEM \\
\hline \multirow[t]{3}{*}{1} & Alanine aminopeptidase & 0.59 & 0.15 & - & - & 0.57 & 0.14 \\
\hline & $\gamma$-Glutamyltransferase & 0.47 & 0.15 & 0.57 & 0.14 & - & - \\
\hline & Creatinine & 0.11 & 0.04 & 0.14 & 0.06 & 0.12 & 0.04 \\
\hline \multirow[t]{3}{*}{2} & Alanine aminopeptidase & 0.16 & 0.066 & - & - & 0.35 & 0.08 \\
\hline & $\gamma$-Glutamyltransferase & 0.16 & 0.06 & 0.35 & 0.08 & - & - \\
\hline & Creatinine & 0.16 & 0.04 & 0.12 & 0.03 & 0.18 & 0.03 \\
\hline \multirow[t]{3}{*}{3} & Alanine aminopeptidase & 0.27 & 0.09 & - & - & 0.23 & 0.10 \\
\hline & $\gamma$-Glutamyltransferase & 0.33 & 0.10 & 0.23 & 0.10 & - & - \\
\hline & Creatinine & 0.16 & 0.051 & 0.15 & 0.059 & 0.14 & 0.036 \\
\hline
\end{tabular}

caseptan periods $(7 \pm 1$ days) were rarely observed among the dominant periods.

The mean periods (fig. 4) displayed an inverted Ushaped dependency on age, i. e. the highest values were observed in the middle age. Although similar for all enzymes, the difference was only significant in the case of dipeptidyl peptidase IV excretion. Figures 5-7 give representative examples of the excretion patterns of the different age groups together with the corresponding maximum entropy method spectra. In none of the age groups were the mean periods significantly different among the three enzymes.

The correlation analysis of the individual excretion patterns as well as the mean coefficients of determination disclosed that the excretion of all three brush-border enzymes is most tightly correlated in the early childhood. Although the individual correlations displayed a high variance in all age groups, mean coefficients of determination of between 0.47 and 0.59 (tab. 1) and individual coefficients between 0.8 and 0.9 as found for volunteers 3 and 5, indicate a strong synchronization among the infradian excretion rhythms of alanine aminopeptidase, dipeptidylpeptidase IV and $\gamma$-glutamyltransferase. In all age groups the correlation between enzyme and creatinine excretion was low (tab. 1).

\section{Discussion}

Most of the previous studies that have focused on rhythmic changes of renal enzymes activities and of enzymuria dealt with circadian changes $(4,24,25)$. Only a few investigators reported on infradian rhythms in enzyme excretion $(12,13,17)$. In humans, the excretion of the brush border enzymes dipeptidylpeptidase IV, $\gamma$-glutamyltransferase, and alanine aminopeptidase displayed infradian periods between 2 and 44 days (12). Under the conditions of an aminoglycoside therapy an increased occurrence of circaseptan periods in the alanine aminopeptidase excretion was noticed $(13,19)$, which was in agreement with the hypothesis that these periods are particularly abundant during reactive and adaptive phases of the organism (20). The data that are known about enzyme excretion in laboratory animals do not support species differences. In rat, Grötsch et al. $(16,17)$ found infradian alterations in the excretion of alanine-aminopeptidase, $\mathrm{N}$-acetyl- $\beta$ - $D$-glucosaminidase and $\gamma$-glutamyltransferase in the range of 7 and 9 days, i.e. in or close to the circaseptan range ( $7 \pm 1$ days). Although in mice a broad spectrum of periods in the excretion of brush border enzymes was observed (ranging from circadian periods up to 12 days (18)), such differences seem to depend rather on the experimental conditions (such as sampling interval) than express true species differences. The present study on human volunteers is the first to our knowledge that focused on ontogenetic changes of the infradian rhythms in enzymuria. The employed age groups represented such important life-stages as childhood, adulthood and senescence.

The high mean values of enzyme excretion during the early childhood obtained in this study are in accordance with previous findings $(26,27)$. The peak of enzyme excretion during this age can be caused by an enhanced cell turnover (9) and/or may be partly a consequence of the low concentration of the reference analyte creatinine $(9,16,26)$ at this age. Although the age-dependency in the reference analyte creatinine may be superimposed on the age-dependent changes of the enzyme excretion, they can be excluded from being decisive for the following reasons:

(I) If the pattern would be caused by the age-dependency of creatinine then it should be the same across all investigated enzymes. However, comparing the age-dependency of dipeptidyl peptidase IV (U-shaped) and $\gamma$-glutamyltransferase (linear decline with age) this is clearly not the case. 
(II) The enzyme activities of the brush border enzymes in mice (calculated either per protein or fresh weight of the kidneys) also display a clear age-dependency (Balschun; unpublished results) supporting that the agedependency found in the excretion of these enzymes is due to a physiological maturation rather than an artefact caused by the chosen reference analyte.

Since the rhythmic analysis by maximum entropy method detected ontogenetic changes in the infradian rhythms of alanine aminopeptidase, dipetidylpeptidase IV and $\gamma$-glutamyltransferase excretion, both the overall enzyme excretion and its periodicity appear to be agedependent. The range of infradian periods from 2 to 35 days found in this investigation as well as the scarce occurrence of circaseptan periods are in line with our earlier reports $(12,13,19)$.

Although the physiological significance of the artificial parameter "mean period" is still unclear, we suggest that the inverted U-shaped dependence of enzyme excretion on age reflects a higher stability of the rhythmic order during adulthood and a greater vulnerability of the internal periodicity during childhood and at the higher age. However, the indicative value of the "mean period" has to be proven in further studies.

A challenging question of this and all other studies about infradian changes in enzyme excretion is wether or not these rhythms are driven by internal pacemakers. Grötsch et al. (16) found in rats seasonal rhythms in the excretion of alanine aminopeptidase and four other enzymes under constant lighting conditions, indicating that these changes were endogenously generated. Circaseptan alterations were reported to persist in human sub-

\section{References}

1. Jung $K$. Enzyme activities in urine: how should we express their excretion? Eur J Clin Chem Clin Biochem 1991; 29:725-9.

2. Guder WG, Hofmann W. Markers for the diagnosis and monitoring of renal tubular lesions. Clin Nephrol 1992; 38:3-7.

3. Hofmann W, Guder WG. A diagnostic programme for quantitative analysis of proteinuria. J Clin Chem Clin Biochem 1989; 27:589-600.

4. Schirrow R, Wesslau C, Jung K. Zur Ausscheidungsrhythmik verschiedener Harnenzyme bei Ratten. Nieren- und Hochdruckkrankh 1987; 16:407.

5. Grötsch H, Fuchs E, Simane ZJ. Reference values. In: Jung $\mathrm{J}$, Mattenheimer $\mathrm{H}$, Burchardt $\mathrm{U}$, editors. Urinary enzymes in clinical and experimental medicine. Berlin: Springer Verlag, 1992:253-6.

6. Burchardt U, Scherberich JE. External diseases. In: Jung K, Mattenheimer $\mathrm{H}$, Burchardt $U$, editors. Urinary enzymes in clinical and experimental medicine. Berlin: Springer-Verlag, 1992:223-44.

7. Tominaga M, Fujiyama $\mathrm{K}$, Hoshino $T$, Tanaka $Y$, Takeuchi $T$, Honda $\mathrm{M}$, et al. Urinary $\mathrm{N}$-acetyl- $\beta$-D-glucosaminidase in the patients with hyperthyroidism. Horm Metabol Res 1989; 21:438-40.

8. Jung K, Scholz D. An optimized assay of alanine aminopeptidase activity in urine. Clin Chem 1980; 26:1251-4. jects which were free-running for the calendar week $(20$, 28 ). In the present investigation we found no conspicuous indication that the rhythms were either influenced by the calendar week or the working and life-schedule. Therefore, it seems likely that the infradian rhythms in enzymuria are predominantly endogenously driven, similar as shown for ultradian and circadian changes (29, 30). However, in contrast to the latter it can be suggested that infradian changes in enzymuria are most susceptible to external factors, which may result in a modification or masking of the overt rhythms.

The results of the correlation analysis suggest that the physiological processes resulting in the excretion of alanine aminopeptidase, dipeptidylpeptidase IV and $\gamma$-glutamyltransferase are correlated, but that there is not a direct functional link. This view is supported by the high inter-individual variance of correlation found in this study and by data of other authors. Whereas Pagien \& Peterson (31) described a coordinated release of several lysosomal enzymes, Holmes et al. (32) reported daily differences in the correlation of enzyme excretion of lysosomal and brush border enzymes and Gibey et al. (14) noted a discordancy of enzymuria under gentamicin treatment.

Therefore, it appears that under similar circumstances the coordination in the excretion of certain enzymes may be quite variable. The mechanisms that are responsible for such changes in the coordination of enzyme excretion need further investigation. The available evidence suggests that the internal pacemakers responsible for the circadian and infradian overt rhythms in enzymuria may play a central role in the regulation and coordination of enzyme excretion.

9. Scherberich JE. Clinical interpretation of urinary enzyme excretion. In: Jung $\mathrm{K}$, Mattenheimer $\mathrm{H}$, Burchardt $U$, editors. Urinary enzymes in clinical and experimental medicine. Berlin: Springer-Verlag, 1992:161-238.

10. Jung K, Pergande M, Schimke E, Ratzmann KP. Harnenzyme und niedermolekulare Proteine als Indikatoren der diabetischen Nephropathie. Klin Wochenschr 1989; 67:27-30.

11. Jung K, Pergande M, Schulze BD, Precht K, May G. Niedermolekulare Proteine im Serum und Urin bei nephrologischen Fragestellungen. Biochemie - Pathobiochemie - klinische Bedeutung. Z Klin Med 1989; 44:549-56.

12. Burchardt $U$, Winkler $K$, Klagge $M$, Balschun D, Barth A. Infradian biorhythms of enzymuria in man? J Clin Chem Clin Biochem 1988; 26:491-6.

13. Balschun $D$, Burchardt $U$, Klagge $M$, Stein W. Infradian rhythms of alanine aminopeptidase excretion during gentamicin therapy. Eur J Clin Chem Clin Biochem 1991; 29:783-6.

14. Gibey R, Dupond J-L, Alber D, Leconte des Floris R, Henry J-C. Predictive value of urinary N-acetyl-beta-D-glucosaminidase (NAG), alanine-aminopeptidase (AAP) and beta-2-microglobulin $\left(\beta_{2} M\right)$ in evaluating nephrotoxicity of gentamicin. Clin Chim Acta 1981; 116:25-34.

15. Balschun D, Janke S, Schuh J. The valence of photoperiod and feeding as 'Zeitgebers' of the kidney rhythms of peptidecleaving enzymes. In: Gutenbrunner Ch, Hildebrandt G, Moog 
R, editors. Chronobiology, chronomedicine. Frankfurt/MainBern-New York-Paris: Peter Lang, 1991:151-6.

16. Grötsch H, Hropot M, Klaus E, Wesely J. Influences of seasonal biorhythms on urinary excretion of enzymes and other parameters. J Clin Chem Clin Biochem 1990; 28:285-6.

17. Grötsch H, Hropot M, Klaus E, Malerczyk V, Mattenheimer $H$. Enzymuria of the rat: biorhythms and sex differences. J Clin Chem Clin Biochem 1985; 23:343-7.

18. Balschun D, Burchardt U, Janke S, Stein W. Infradian rhythms in the excretion of microvillar peptide-cleaving enzymes. In: Diez-Noguera A, Cambras T, editors. Chronobiology and chronomedicine. Frankfurt am Main: Peter Lang, 1992:203-9.

19. Burchardt U, Schinköthe G, Müller G, Neef L, Krosch H. Ausscheidungskinetik von Enzymen und Proteinen mit dem Harn bei Applikation therapeutischer Gentamycindosen. Schweiz Med Wochenschr 1978; 108:1541-5.

20. Hildebrandt G, Geyer F. Adaptive significance of circaseptan reactive periods. J Interdiscipl Cycle Res 1984; 15:109-17.

21. Werner M, Maruhn D, Atoba M. Use of gel filtration in the assay of urinary enzymes. J Chromatogr 1969; 40:254-63.

22. Peters JE, Schneider I, Haschen RJ. Bestimmung der L-Alanyl-peptidhydrolase (Alanin-Aminopeptidase, AminosäureAryl-amidase) im menschlichen Harn. Clin Chim Acta 1972; 36:289-301.

23. Jung K, Pergande M, Schröder K, Schreiber G. Influence of $\mathrm{pH}$ on the activity of enzymes in urine at $37^{\circ} \mathrm{C}$. Clin Chem $1982 ; 28: 1814$.

24. Balschun D, Lojda Z, Schuh J. Rhythmic changes of dipeptidyl peptidase IV activity in the blood and in the kidney of mice: biochemical and histochemical investigation. Biol Zentrbl 1988; 107:181-8.

25. Feldmann D, Flandrois C, Jardel A, Phan T-M, Aymard P. Circadian variations and reference intervals for some enzymes in urine of healthy children. Clin Chem 1989; 35:864-7.
26. Jung K, Hempel A, Grützmann K-D, Hempel R-D, Schreiber G. Age-dependent excretion of alanine aminopeptidase, alkaline phosphatase, $\gamma$-glutamyltransferase and $N$-acetyl- $\beta$-D-glucosaminidase in human urine. Enzyme 1990; 43:10-6.

27. Jung K, Schulze G, Reinhold C. Different diuresis-dependent excretion of urinary enzymes: $\mathrm{N}$-acetyl- $\beta$-D-glucosaminidase, alanine aminopeptidase, alkaline phosphatase and $\gamma$-glutamyltransferase. Clin Chem 1986; 32:529-32.

28. Halberg F, Reinberg A. Rhythmes circadiens et rhythmes de basses frequences en physiologie humaine. J Physiol 1967; $59: 117-20$.

29. Ashoff J. Features of circadian rhythms relevant for the design of shift schedules. Ergonomics 1978; 21:739-54.

30. De Vecchi A, Halberg F, Sothern RB, Cantaluppi A, Ponvicelli C. Circaseptan rhythmic aspects of rejection in treated patients with kidney transplant. In: Walker CA, Winget CM, Soliman KFA, editors. Chronopharmacology and chronotherapeutics. University Foundation, Tallahassee 1981:339-53.

31. Paigen K, Peterson J. Coordinacy of lysosomal enzyme excretion in human urine. J Clin Invest 1978; 61:751-62.

32. Holmes RP, Graddock G, Espeland MA, Assimos DG, Dean $\mathrm{RH}$. A lack of coordination in the release of urinary lysosomal and brush border enzymes following renovascular surgery. Clin Chim Acta 1989; 18:1-10.

Received October 15, 1996/January 31, 1997

Corresponding author: Prof. Dr. Ulf Burchardt, Klinikum Frankfurt (Oder), Müllroser Chaussee 7, D-15236 Frankfurt (Oder), Germany 